\title{
Study of the Thermal Internal Boundary Layer in Sea Breeze Conditions Using Different Parameterizations: Application of the WRF Model in the Greater Vitória Region
}

\author{
Nadir Salvador ${ }^{1}$, Ayres G. Loriato ${ }^{1}$, Alexandre Santiago ${ }^{2}$, Taciana T.A. Albuquerque ${ }^{2}$, \\ Neyval C. Reis Jr. ${ }^{2}$, Jane M. Santos ${ }^{2}$, Eduardo Landulfo ${ }^{3}$, Gregori Moreira ${ }^{3}$, Fábio Lopes ${ }^{3}$, \\ Gerhard Held ${ }^{4}$, Davidson M. Moreira ${ }^{5}$ \\ ${ }^{1}$ Departamento de Tecnologia Industrial, Universidade Federal do Espírito Santo, \\ Vitória, ES, Brasil. \\ ${ }^{2}$ Departamento de Engenharia Ambiental, Universidade Federal do Espírito Santo, \\ Vitória, ES, Brasil. \\ ${ }^{3}$ Instituto de Astronomia, Geofísica e Ciências Atmosféricas, Universidade de São Paulo, \\ São Paulo, SP, Brasil. \\ ${ }^{4}$ Centro de Meteorologia de Bauru, Bauru, SP, Brasil. \\ ${ }^{5}$ Serviço Nacional de Aprendizagem Industrial, Salvador, BA, Brasil.
}

Received: 12/8/2015 - Accepted: 22/2/2016

\begin{abstract}
In the present study, the physical parameterizations of the Weather Research and Forecasting (WRF) model are verified for making accurate inferences about the dynamics of the Thermal Internal Boundary Layer (TIBL) generated by sea breeze in an urban center with an island in a bay along a coastal region with rugged topography. The simulations were performed using parameterizations from Yonsei University (YSU), Mellor-Yamada-Janjic (MYJ) and Asymmetric Convective Model version 2 (ACM2) for the atmospheric boundary layer (ABL) and Noah and Rapid Update Cycle (RUC) for the Land Surface Model (LSM). The data inferred by the WRF model were compared with those obtained by a Surface Meteorological Station (SMS) and by measurements generated using Light Detection and Ranging (LIDAR), Sonic Detection and Ranging (SODAR) and radiosonde. The simulations showed that although the object of this research was a region with high geographical complexity, the YSU parameterization set (non-local closure) for the ABL and the Noah parameterization for the LSM presented satisfactory results in determining ABL height generated by the sea breeze on the day in question.
\end{abstract}

Keywords: sea breeze, WRF, LIDAR, SODAR, parameterization, thermal internal boundary layer.

\section{Estudo da Camada Limite Interna Térmica em Condições de Brisa do Mar, Utilizando Diferentes Parametrizações: Aplicação do Modelo WRF na Região da Grande Vitória}

\begin{abstract}
Resumo
No presente estudo, é pesquisada a acurácia de parametrizações físicas do modelo Weather Research and Forecasting $(W R F)$ em fazer inferências sobre a dinâmica da camada limite interna térmica $(T I B L)$ gerada pela brisa do mar, em um centro urbano com uma ilha contida em uma baía, ao longo de uma região costeira com topografia acidentada. As simulações foram realizadas utilizando as parametrizações Yonsei University (YSU), Mellor-Yamada-Janjic (MYJ) e Asymmetric Convective Model versão 2 ( $A C M 2)$ para camada limite atmosférica $(A B L)$ e Noah e Rapid Update Cycle $(R U C)$ para modelo de superfície da terra (LSM). Os dados inferidos pelo modelo $W R \mathrm{~F}$ foram comparados com os obtidos por uma estação meteorológica de superfície $(S M S)$ e por medições usando Light Detection and Ranging
\end{abstract}

Autor de correspondência: Nadir Salvador, nadir.salvador@ufes.br. 
(LIDAR), Sonic Detection and Ranging (SODAR) e radiossondagem. As simulações mostraram que, embora o objeto desta pesquisa seja em uma região com alta complexidade geográfica, o conjunto de parametrização $Y S U$ (fechamento não local) para a $A B L$ e a parametrização Noah para $L S M$ apresentaram resultados satisfatórios na determinação da altura da $A B L$ gerada pela brisa do mar, no dia em questão.

Palavras-chave: brisa marítima, WRF, LIDAR, SODAR, parametrização, camada limite interna térmica.

\section{Introduction}

Along coastal regions, the atmospheric boundary layer (ABL) has a different behavior further inland because of daily variations in the thermal differential between the ocean and land, which can significantly alter local circulation. Thus, the dynamics of the thermal internal boundary layer (TIBL), which is formed by sea breezes, has been studied by many researchers, including Estoque (1962), Simpson (1996), Miller et al. (2003), Levy et al. (2009), Papanastasiou et al. (2010), Crossman and Horel (2010), Soler et al. (2011), Muppa et al. (2012), Cheng et al. (2012), De León and Orfila (2013) and Hernandéz-Ceballos et al. (2013). In these studies, in addition to the specific visualization of the phenomenon, in which the influence of sea breezes on local circulation is shown to affect the dispersion of pollutants, mathematical models are evaluated for making predictions about these circulations, particularly studies on the influence of the parameterizations used in the models, which require further analyses of this type of situation.

Pollutants are transported over long distances by a large-scale wind field, and their dispersion is a result of a set of vortices of multiple dimensions generated by imbalances within the large scales by several factors, such as thermal differentials, terrain, types and use of soils, etc. (Stull, 1988). Such factors create turbulence and movements on a smaller scale, which have an important role in the dispersion of air pollutants. However, other factors, such as sea breezes, can occasionally contribute to increasing concentrations of pollutants, thus causing nuisances and health damage for individuals living close to emission sources (Borrego et al., 2007). The TIBL entraps the pollutants released close to the ground, which may also be reintroduced via the fumigation effect (the penetration of pollutants that are above the TIBL), thereby increasing their concentrations in areas close to large volumes of water (Bouchlaghem et al., 2007; Boyouk et al., 2011). Thus, a more realistic reproduction of the TIBL in a mesoscale model is crucial for accurate subsequent modeling and evaluations of air quality in a given region.

The main objective of this study is to evaluate the performance of certain physical parameterizations of the mesoscale Weather Research and Forecasting (WRF) model in detecting and characterizing sea breeze dynamics, which can influence studies examining the effects of new potentially polluting enterprises in the vicinity of the Greater Vitória Region (GVR) in the state of Espírito Santo, Brazil. To validate the simulations, observational data were collected using Light Detection and Ranging (LIDAR), Sonic Detection and Ranging (SODAR), radiosonde and a Surface Meteorological Station (SMS). Importantly, it is difficult to detect and characterize the sea breeze on consecutive days during an experimental trial, which is typically short-lived because of the costs involved and dependency on weather conditions. Thus, this study presents the comparative numerical modeling results using experimental data from a one-day trial conducted in 2012 on sea breeze in the GVR. The literature also presents many articles that use only one day of analysis for sea breeze studies (Chiba, 1997; Gilliam et al., 2004; Talbot et al., 2007; Dandou et al., 2009; Challa et al., 2009; Kala et al., 2010; De tomasi et al., 2011; Soler et al., 2011; Chemel and Sokhi, 2012; Ryu et al., 2012; Molina et al., 2014; Varquez et al., 2015). Therefore, this case study is an exercise of evaluating parameterizations in a coastal region, accounting for a comparison with observed data obtained with different measurement equipment.

This article is organized in the following manner: Section 2 presents the sequence in which the research was performed and details the basic characteristics of the domains used, such as the dimensions, spacing of horizontal and vertical grids, geographical characteristics and singularities, wind regimes, reference data obtained and the physical parameterizations used in the simulations of the WRF model. Section 3 presents the results generated by the WRF model, and the accuracy of each set of parameterizations in describing the occurrence and dynamics of sea breezes is evaluated, comparing the data predicted by the model with those obtained by the instruments used during the experimental period. Finally, Section 4 reports the accuracy of the physical parameterizations of the WRF model, indicating which results were closer to those obtained by the instruments used during the experimental period.

\section{Methodology}

Below, the following are briefly shown: the main aspects related to the study field, the predominance of winds in the region, the use of equipment for collecting the experimental data, the grid used in the WRF simulations, and the respective parameterizations tested in this study.

\subsection{Study field}

The study field, shown in Fig. 1, is characterized by an urban center with a population of approximately 1.5 million inhabitants. The region also possesses complex topog- 


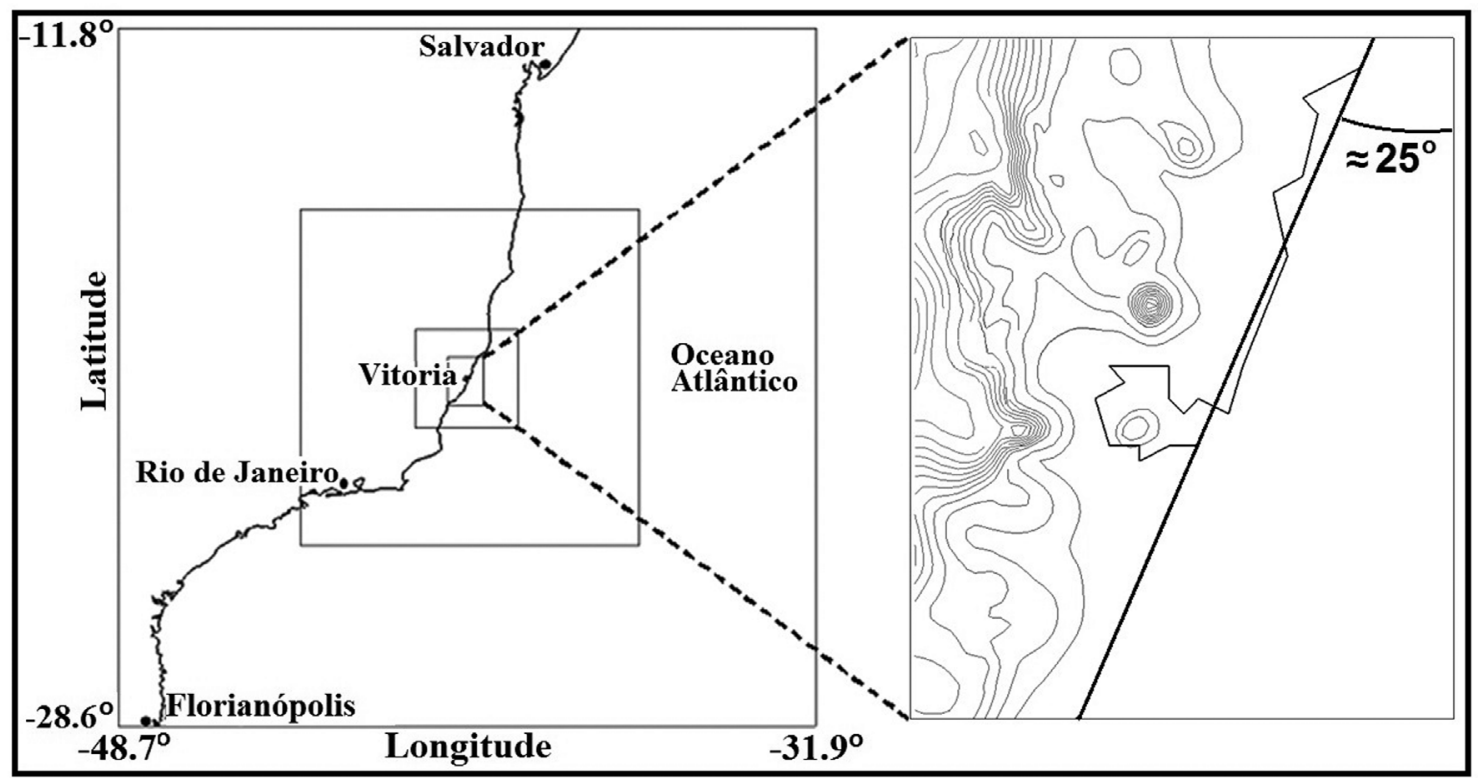

Figure 1 - Nesting domains and study domain relief.

raphy with a flat portion near the coast running from north to south of the GVR, permeated by several peaks with altitudes of up to $833 \mathrm{~m}$ and a chain of mountains parallel to the coast with altitudes exceeding $1,300 \mathrm{~m}$. Therefore, this region has various singularities that influence local circulations and consequently, the transportation and dispersion of pollutants.

\subsection{Wind regimes in the region}

The wind regime in the GVR is influenced by the South Atlantic Subtropical High (SASH), which consequently influences the formation of the South Atlantic Convergence Zone (SACZ). During spring and summer, the high-pressure system occurs further south and zonally moves further east (above the central region of the Atlantic Ocean). Therefore, the prevailing winds in the GVR are in the N-NE direction. During winter, the presence of the SASH close to the mainland encourages the formation of thermal inversion and stability, thereby concentrating pollutants in layers closest to the surface of the main urban centers of the south and southeast regions. The intensity of the SASH increases during winter with average values of $1023 \mathrm{hPa}$, and the center moves farther north and west, thus enhancing trade winds from the southeast. Therefore, there is a change in direction at this time of year (Mendonça and Bonatti, 2008).

The compass roses (Fig. 2) show the wind directions during four seasons from December 22, 2011 to December 21, 2012.

The prevailing winds in spring occur in a N-NE direction with some periods of southern winds caused by the entry of cold fronts and winds in a NW direction. This result suggests the presence of land breezes. In summer, there was a high prevalence of N-NE winds with few southerly fronts and light winds in the northwest direction. During autumn, the prevailing winds were in a N-NE and S-SW direction with higher speeds and weaker winds with a W-NW and $\mathrm{S}$-SE direction. In winter, despite large variations in the prevailing wind direction, there was an increase in periods of eastern and W-NW winds.

The analysis of the compass roses suggests the presence of sea breezes, particularly in winter, which can hinder the dispersion of particulate matter in eventual episodes of pollutant discharge into the atmosphere. Several studies show that increasing the concentration of particulate matter in the atmosphere generates various public health problems and affects the quality of life of individuals who live or work in the study areas (Saldiva et al., 1995; Bell et al., 2006). The identical process of accumulating particulate matter in the atmosphere may occur in the GVR because of the angle formed by the coastline and spatial positioning of urban areas and pollution sources.

In the region, the industries with the greatest pollutant potential are located together on the coastline, which has a meridian angle of approximately 25 degrees. These facts suggest that the most critical situations should occur in conditions with winds in an easterly direction. Therefore, any deviations in the wind field because of the sea breeze causes atmospheric pollutants to reach the study field because of the effect of fumigation resulting from the inversion caused by the breeze. This effect affects the population, who mostly dwell in the vicinity of potential emission sources.

During the experimental period (7/24/2012 to $8 / 1 / 2012$ ), there were several migratory anticyclones with subtropical characteristics associated with $\mathrm{SASH}$, which was positioned between 10 and $33 \mathrm{~W}$ over most of the ocean but influenced the circulation of the entire east Bra- 

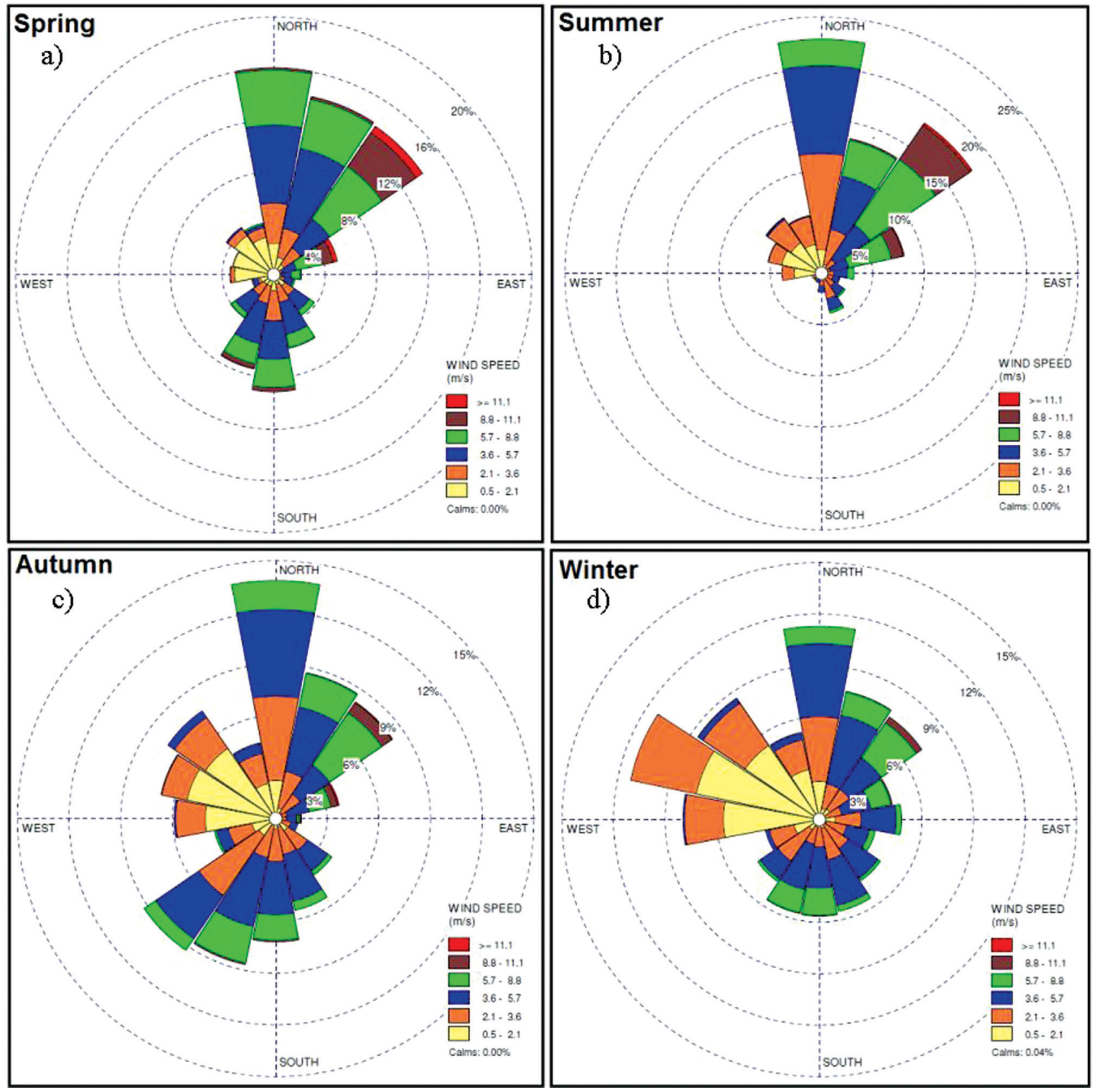

Figure 2 - Rose of the wind for all seasons.

zilian coast. Simultaneously, a stationary front remained for most of the period to the south at latitude $20 \mathrm{~S}$ over the Atlantic Ocean, occasionally disturbing the weather conditions of the GVR. On July 25 and 30, 2012, there were tendencies of a cold front (CF) that was not confirmed. On July 31, SASH was further south of its climatological position with a center of $1034 \mathrm{hPa}$ east of $10 \mathrm{~W}$, allowing for increased influence of the CF in the GVR, which is located on the southern coast of Rio de Janeiro. Consequently, July 31 showed the largest wind speeds and an increase in cloudiness and precipitation.

\subsection{Measurement equipment}

From $7 / 24$ to $8 / 01$ during the winter of 2012 , in a joint operation with teams from the Federal University of Espírito Santo (Universidade Federal do Espírito Santo UFES), the Institute of Meteorological Research (Instituto de Pesquisas Meteorológicas - IPMet), University of São Paulo (Universidade de São Paulo - USP) and the Institute of Nuclear and Energy Research (Instituto de Pesquisas Energéticas e Nucleares - IPEN), an experiment was conducted to survey atmospheric data in the GVR. The experiment used SODAR, Scintec MFAS: Flat Array Sodar, 
emitting 10 frequencies $(1650$ - 2750), which was programmed for a vertical resolution of 10 to $30 \mathrm{~m}$, a maximum height of $800 \mathrm{~m}$, a moving average of $30 \mathrm{~min}$ and a LIDAR system, Laser Nd: YAG - Quantel CFR 200 with $532 \mathrm{~nm}$ wavelength, $20 \mathrm{~Hz}$ repetition rate, beam divergence $<0.5 \mathrm{mrad}$, Cassegrain telescope with a $20 \mathrm{~cm}$ diameter, $1 \mathrm{mrad}$ field of vision (FOV), $180 \mathrm{~m}$ overlap, and two photomultiplier tools (PMTs) forming two detection channels at 532 and $607 \mathrm{~nm}$ with $1 \mathrm{~nm}$ FWHM interference filters (Landulfo et al., 2009). The data on the vertical distribution of aerosols were obtained using a $7.5 \mathrm{~m}$ vertical resolution and temporal resolution of approximately $2 \mathrm{~min}$. Approximately $6 \mathrm{~km}$ from the location where the instruments were located, daily launches of meteorological probes were conducted at two times: 9:00 and 21:00 (local time). The equipment locations (LIDAR, SODAR and SMS), radiosonde launch sites and the locations of potential pollution industries are shown in Fig. 3.

Some mesoscale meteorological phenomena, including sea breezes, influence local circulation and increase the complexity of the ABL profile. These circulations result in sublayers with different profiles, and unique turbulent regimes are created in each ABL sublayer (Haurwitz, 1947; Fisher, 1961; Simpson, 1994; Miller et al., 2003). Thus, the $\mathrm{ABL}$ height is an important parameter because it is the region where convection and low-level circulations occur. The rapid emergence of a new layer of aerosols when obtaining the vertical distribution of particles using the LIDAR system can result in the development of the TIBL associated with the onset of a sea breeze.

LIDAR emits a pulsed beam into the atmosphere that is backscattered by particles in the atmosphere, returns as a characteristic wavelength and is detected. Because the concentration of particles is changed by the different regimes inside the ABL sublayer interfaces with specific turbulent characteristics, these sublayers can be detected and identified using an analysis of the LIDAR feedback signal.

SODAR is based on the emission of sound pulses in short periods of time and an analysis of the echo captured to determine the average wind pattern in the atmospheric profile. The analysis of the variation in intensity and frequency of the feedback signal provides three components of wind direction $(\mathrm{u}, \mathrm{v}, \mathrm{w})$, and height variations previously defined by the operator. The data obtained by SODAR can be influ-

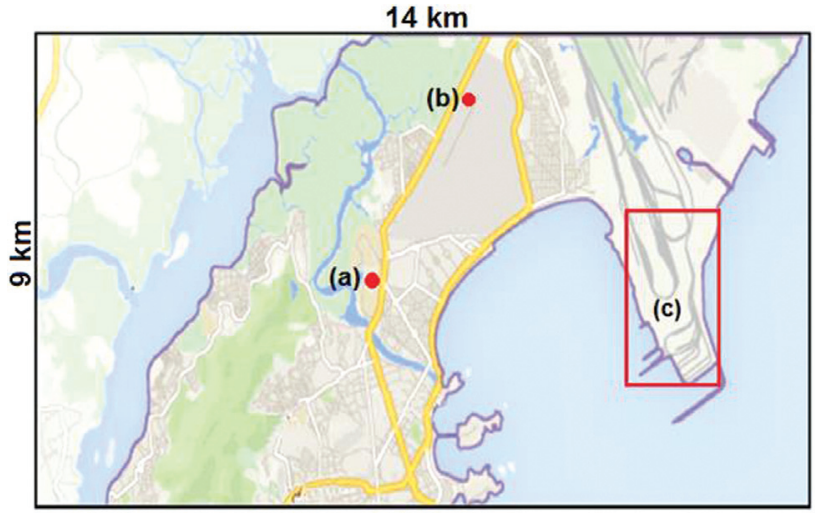

Figure 3 - (a) Location of the SODAR, LIDAR and SMS, (b) The place where the radiosondes are launched and (c) Industrial area.

enced by low humidity in the air, rainfall and ambient noise, thereby changing its reliability and maximum range.

\subsection{WRF computational grid}

Simulations were conducted using the WRF model v.3.4.1 with four nested domains (see Fig. 1) centered at coordinates $20.27 \mathrm{~S}$ and $40.31 \mathrm{~W}$, where the SODAR, LIDAR, and SMS were positioned. The largest three square domains were 1863, 891 and $297 \mathrm{~km}$ with grids of 27,9 and $3 \mathrm{~km}$, respectively, and the study field was $81 \mathrm{~km}$ from north-south, $63 \mathrm{~km}$ from east-west and a $1 \mathrm{~km}$ grid with 55 vertical levels up to approximately $13,400 \mathrm{~m}$, which were more concentrated near the ground with 40 levels up to $400 \mathrm{~m}$ and spaced $10 \mathrm{~m}$ apart.

To initiate the WRF model, geographic data provided by the United States Geological Survey (USGS) were used with a horizontal grid of approximately $1 \mathrm{~km}$, and the data for the atmospheric variables were provided by the NCEP FNL Operational Model Global Tropospheric with a horizontal density of approximately $111 \mathrm{~km}, 26$ vertical levels and a frequency of $6 \mathrm{~h}$.

\subsection{Parameterizations}

The six combinations shown in Table 1 were used in the four fields with three different parameterizations for the ABL (YSU, MYJ and AMC2) and two for the LSM (Noah, RUC) to verify the accuracy of these combinations in sea breeze conditions.

Table 1 - Parameterization used in the study to all domains.

\begin{tabular}{lll}
\hline Set & Planetary Boundary Layer Model (bl_pbl_physics) & Land Surface Model (sf_surface_physics) \\
\hline Set 1 & Yonsei University (YSU) & Rapid Update Cycle (RUC) \\
Set 2 & Mellor-Yamada-Janjic (MYJ) & Rapid Update Cycle (RUC) \\
Set 3 & Asymmetric Convective Model 2(ACM2) & Rapid Update Cycle (RUC) \\
Set 4 & Asymmetric Convective Model 2 (ACM2) & Noah \\
Set 5 & Yonsei University (YSU) & Noah \\
Set 6 & Mellor-Yamada-Janjic (MYJ) & Noah \\
\hline
\end{tabular}


The MYJ parameterization for the ABL is a model of local closure, whereas YSU and ACM2 are for non-local closure. The YSU parameterization implicitly considers non-local flows using a transient term (Pleim and Chang, 1992). The MYJ parameterization uses a turbulence closure model with one and a partial equation from Mellor and Yamada (1982) to represent the turbulence above the surface layer (Janjic, 1994) using a turbulent kinetic energy (TKE) design to infer the coefficient of turbulent diffusion. Mellor and Yamada (1982) argue that the design is suitable for stable and slightly unstable flow, but errors may occur when the flow approaches the free convection boundary. The YSU parameterization is a non-local closure design with a contragradient term in the equation for turbulent diffusion. This equation has been modified from version 3.1 of the WRF model, using the formulation of Hong et al. (2006), by increasing the Richardson number from 0.00 to 0.25 on the soil surface and thus increasing the mixture in the stable boundary layer. The ACM2 parameterization (Pleim, 2007a, b) includes a turbulent diffusion component from the first-order in addition to the original design with non-local explicit transportation from the original ACM1 design (Pleim and Chang, 1992). This modification was conducted to improve the vertical profile near the surface. For neutral and stable conditions, the AMC2 design does not use non-local transportation and uses local closure instead.

For LSM, the RUC parameterization addresses thermal diffusion and the moisture transfer equation from Richards in six levels (Smirnova et al., 2000). The coefficients of soil moisture are specified as a function of 11 soil classes, in addition to turf, as shown by Clapp and Hornberger (1978). The balance of energy and moisture is settled in a thin layer covering the soil surface, and the effect of vegetation in evapotranspiration is accounted for as a function of each of the 11 soil classes.

In the Noah parameterization (Chen and Dudhia, 2001), predictions are generated about soil temperature and moisture in four layers and moisture from vegetation. The surface temperature is calculated by a simple linear equation that translates the energy balance of the soil surface and surface vegetation. Thus, the soil temperature is inferred by solving the thermal diffusion equation from Richards, and the effect of vegetative evapotranspiration is similar to the RUC parameterization. This section considers 16 vegetation classes and 16 soil classes.
The other parameterizations of the model physics, listed in Table 2, remained unchanged for all six simulations, except the cumulus parameterization, which changed to the D3 domain and not the D4 domain because of the grid size of the two internal domains, which were 3 and $1 \mathrm{~km}$ (Skamarock et al., 2008; Wang and Seaman, 2007).

\section{Results}

The predictions generated by the WRF model were compared with data obtained by SMS, LIDAR, SODAR and radiosonde. July 30, 2012 was selected for comparison, a day in which data collected by SMS showed the sea breeze phenomenon. Unfortunately, on this day, LIDAR operation occurred only between 8:00 and 14:00 (because of technical problems). Figure 4 shows, as highlighted, the $\mathrm{ABL}$ and TIBL detected by the instrument.

Using the backscatter signal corrected with the distance obtained by LIDAR during the period, the top of the ABL was approximately $400 \mathrm{~m}$ at 9:00, began to develop, and peaked at $1,600 \mathrm{~m}$ at approximately $12: 45$. Note that there were aerosols dispersed throughout the ABL, but the highest concentration of particulate matter occurred within the TIBL formed by the sea breeze, which peaked at approximately 13:00. The ABL remained above the TIBL, but at that time, the TIBL was below the ABL. The color scale of Fig. 4 is correlated with the total backscatter signal measured by the LIDAR system. The larger the value of the color scale (ranging to red) is, the larger the backscatter signal, which is proportional to the concentration of particulate matter in the atmosphere. This result shows the potential of the LIDAR system in measuring the vertical distribution of aerosols in atmospheric layers (Landulfo et al., 2007).

In addition to the two layers shown in Fig. 4, other layers can be identified below the entrainment zone (approximately $2000 \mathrm{~m}$ ). This result demonstrated the presence of turbulent sublayers with different profiles within the residual layer, where significant changes could be noted in the LIDAR signal because of differences in pollutant concentrations at the layer interfaces.

Figure 5 shows the evolution of the ABL/TIBL height predicted by the simulations conducted by each set of parameterizations of the WRF model compared to those obtained by LIDAR.

Table 2 - Other physical parameterizations used in four grid domains (D1, D2, D3, D4).

\begin{tabular}{lcccc}
\hline Parameterization & D1 & D2 & D3 & D4 \\
\hline Long wave radiation & RRTM & RRTM & RRTM & RRTM \\
Short wave radiation & Dudhia & Dudhia & Dudhia & Dudhia \\
Surface layer & Monin-Obukhov & Monin-Obukhov & Monin-Obukhov & Monin-Obukhov \\
Cumulus & Betts Miller & Betts Miller & New Grell & - \\
\hline
\end{tabular}




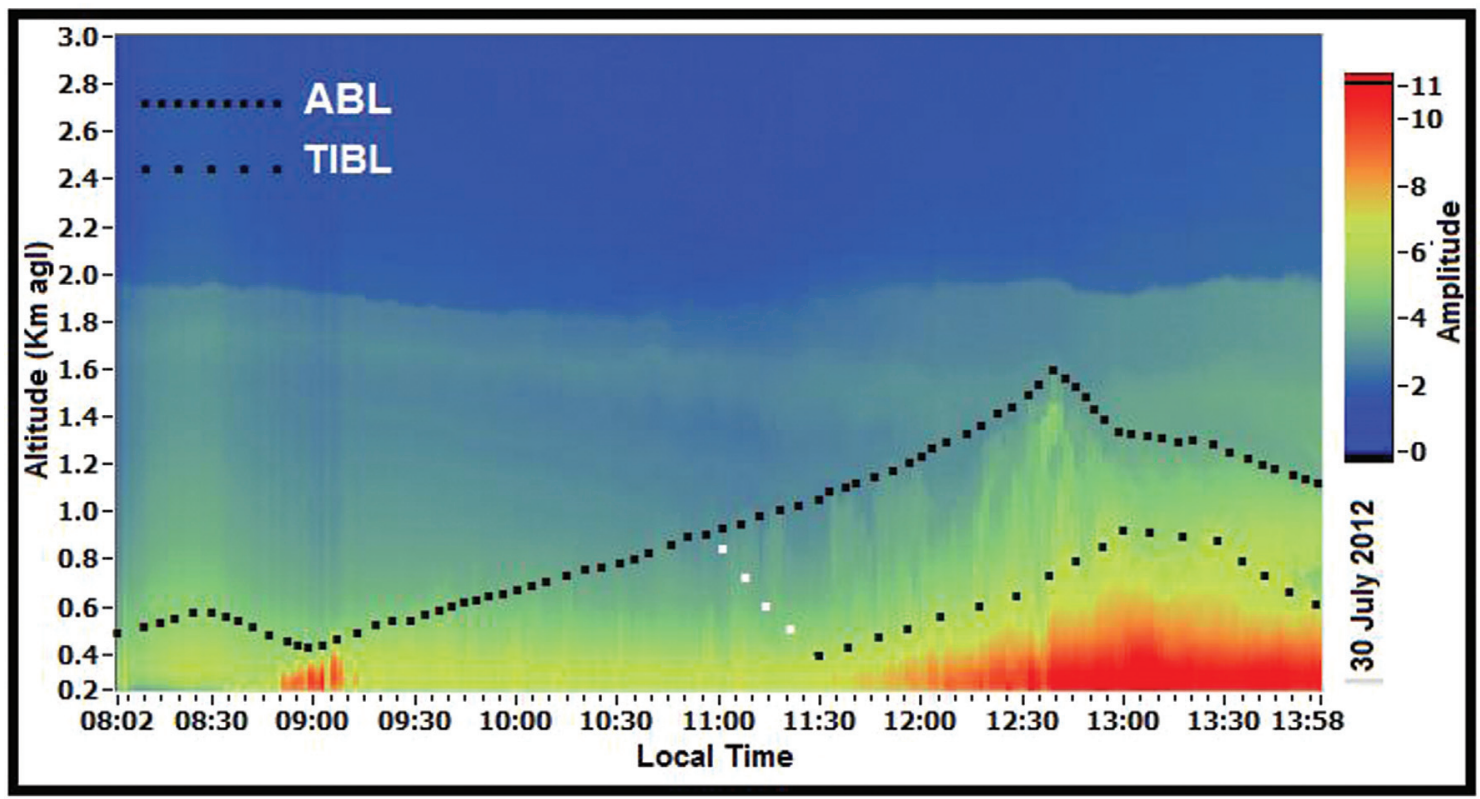

Figure 4 - Temporal evolution of ABL and TIBL obtained by backscatter signal corrected with the distance measured by the LIDAR system.
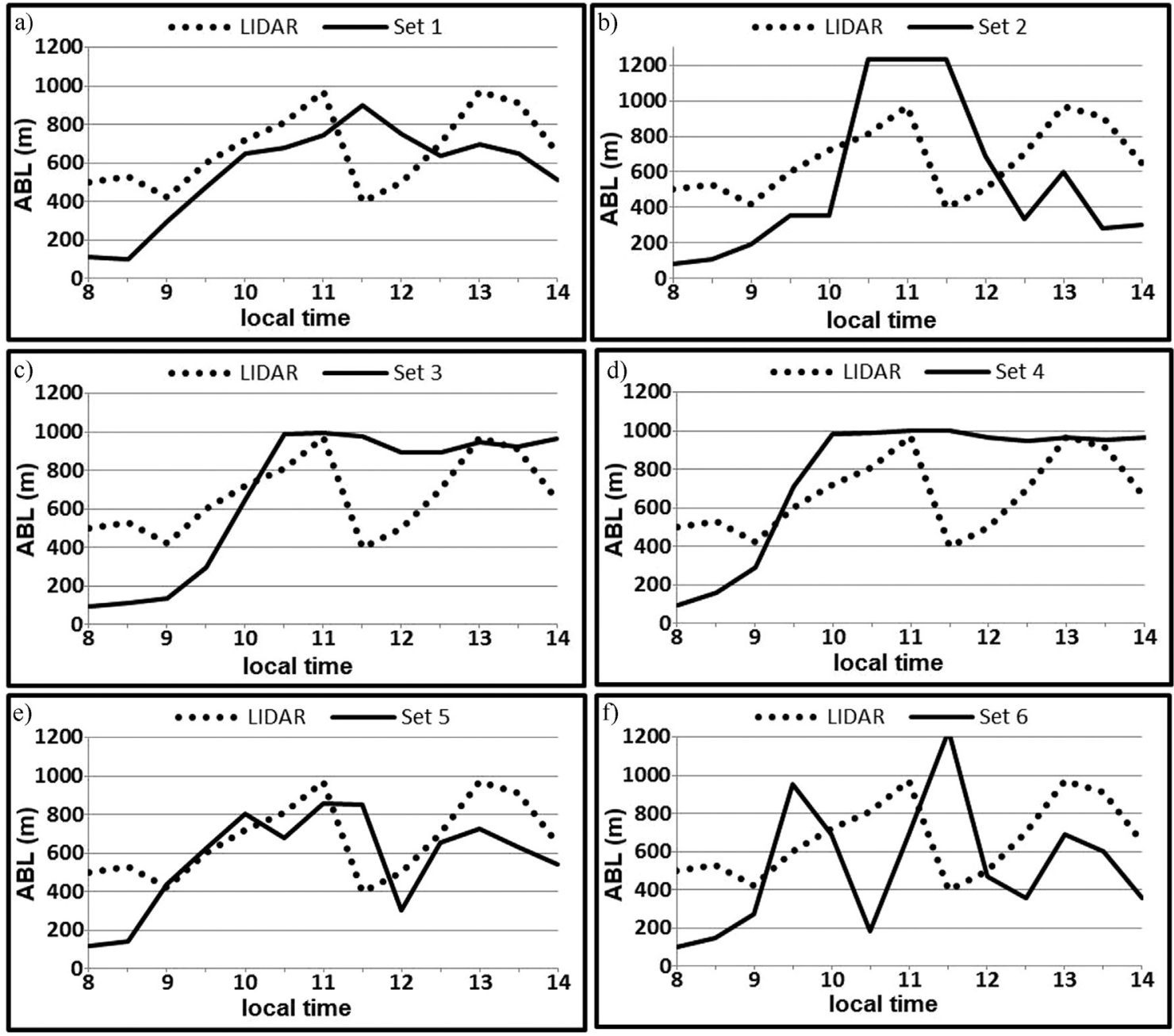

Figure 5 - Comparison between the heights of the ABL and TIBL (LIDAR x WRF). 
Regarding LIDAR, all parameterization sets underestimated the height of the ABL in the early morning, and Sets 3 and 4 did not detect the presence of the sea breeze and predicted the ABL as constant between 10:00 and 14:00. Apparently, Set 1 showed a slight consistency with respect to changes in the heights of both the ABL and TIBL but did not detect the breeze well. Although Sets 2 and 6 also detected the entry of the breeze, Set 5 generated inferences closest to those of LIDAR in practically the entire range. At approximately 11:00, the height of the $\mathrm{ABL}$ was approximately $1,000 \mathrm{~m}$ when suddenly, a breeze entered and caused the collapse of up to $400 \mathrm{~m}$ at approximately 11:30. The ABL increased again and reached a maximum of 1,000 $\mathrm{m}$ at 13:00 and remained approximately constant for a half hour before decreasing again. Unfortunately, the LIDAR data after 14:00 could not be measured. However, the emergence of the breeze and its influence on the emergence of the TIBL was obvious, which was the objective of this study. A similar collapse of the mixed layer, because of sea breeze, was also observed during the 2001 EXCOMPTE experiment in the Marseille area in southern France (Delbarre et al., 2005; Puygrenier et al., 2005).

It is notable that the sea breeze phenomenon has a different behavior depending on the speed and angle that synoptic wind forms with the coastline. In the GVR during the experimental period, the direction of synoptic wind was roughly parallel to the coastline. Because the instruments were located approximately $6 \mathrm{~km}$ from the coastline
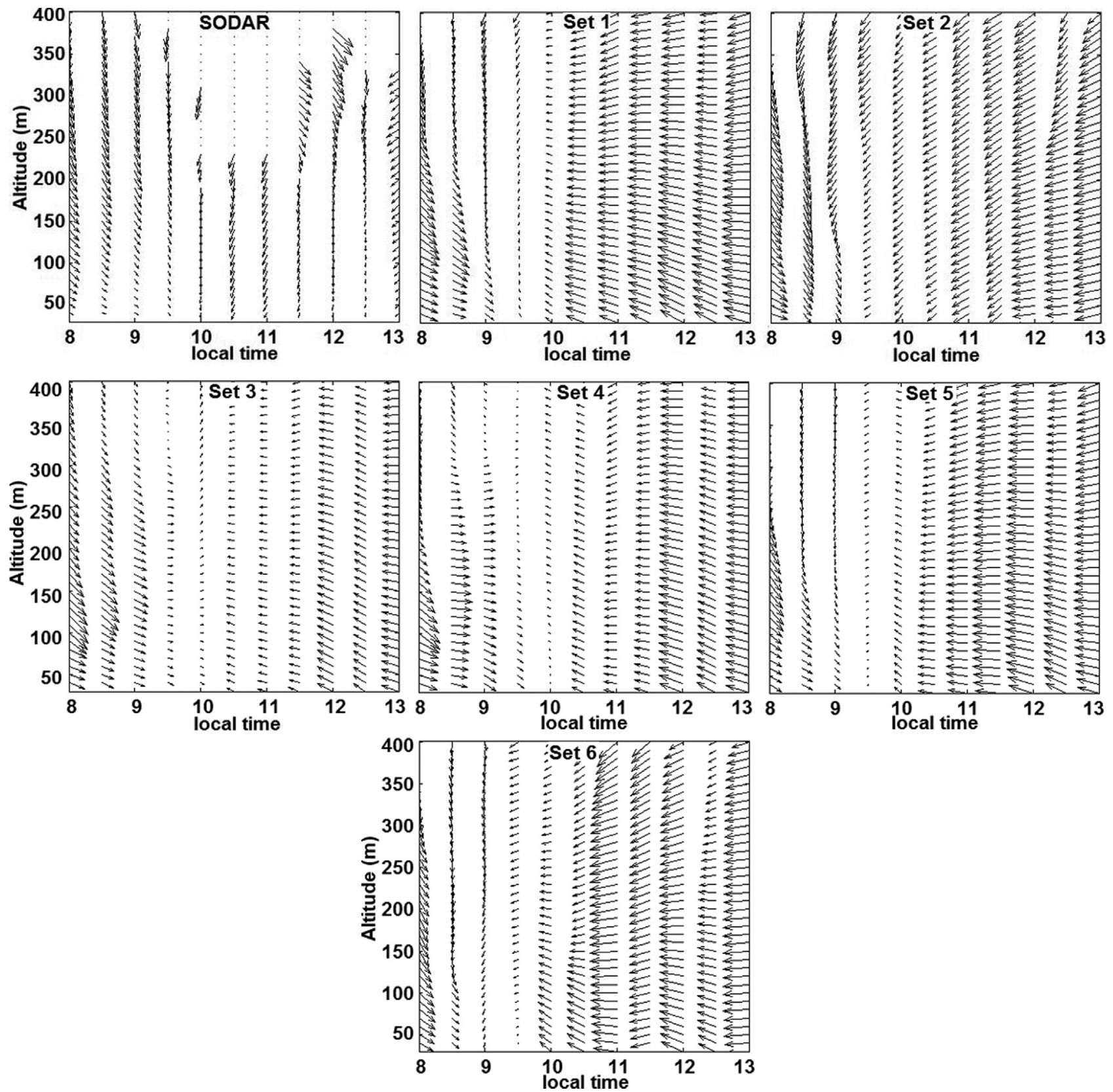

Figure 6 - Wind direction comparing SODAR and WRF simulations. 
(Figs. 1 and 3), the portion of air that reached the location resulted from the portion that entered the shoreline at approximately $18 \mathrm{~km}$. Thus, the height of the TIBL could be large at different measurement points over time. This fact explains that the TIBL began to decrease after 13:30 when the breeze entered the continent at regions closer to the measuring equipment.

A time comparison between the vertical wind patterns inferred from the parameterizations of the WRF model and those obtained by SODAR is shown in Fig. 6.

Between 8:00 and 9:30, the wind direction shown by SODAR had a western vector component, indicating the presence of a land breeze. At 10:30, the wind changed quickly to N-NE, thus suggesting the entrance of a sea breeze. Although all sets detected the entry of the breeze, but at different times, none achieved good inferences about wind direction along the vertical profile compared to the SODAR data.

The vertical velocity $(\mathrm{m} / \mathrm{s})$ profile obtained by SODAR and the six sets of the WRF model is shown in Fig. 7.

When the sea breeze occurred at the measurement point (between 12:00 and 13:00), characteristic rising high vertical speeds were perceived by SODAR. Although less
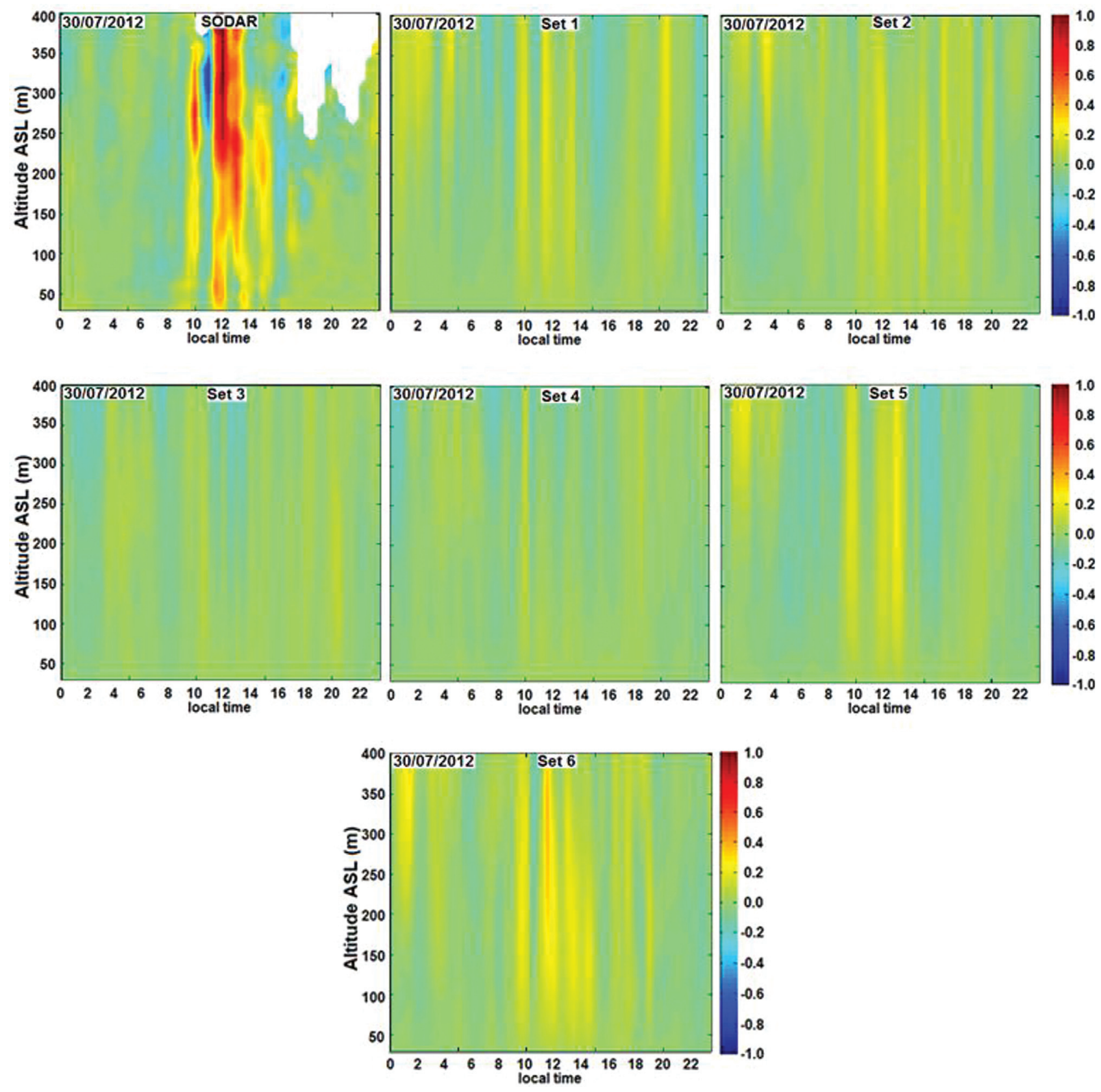

Figure 7 - Comparison SODAR / WRF considering vertical wind speed for all Sets. 

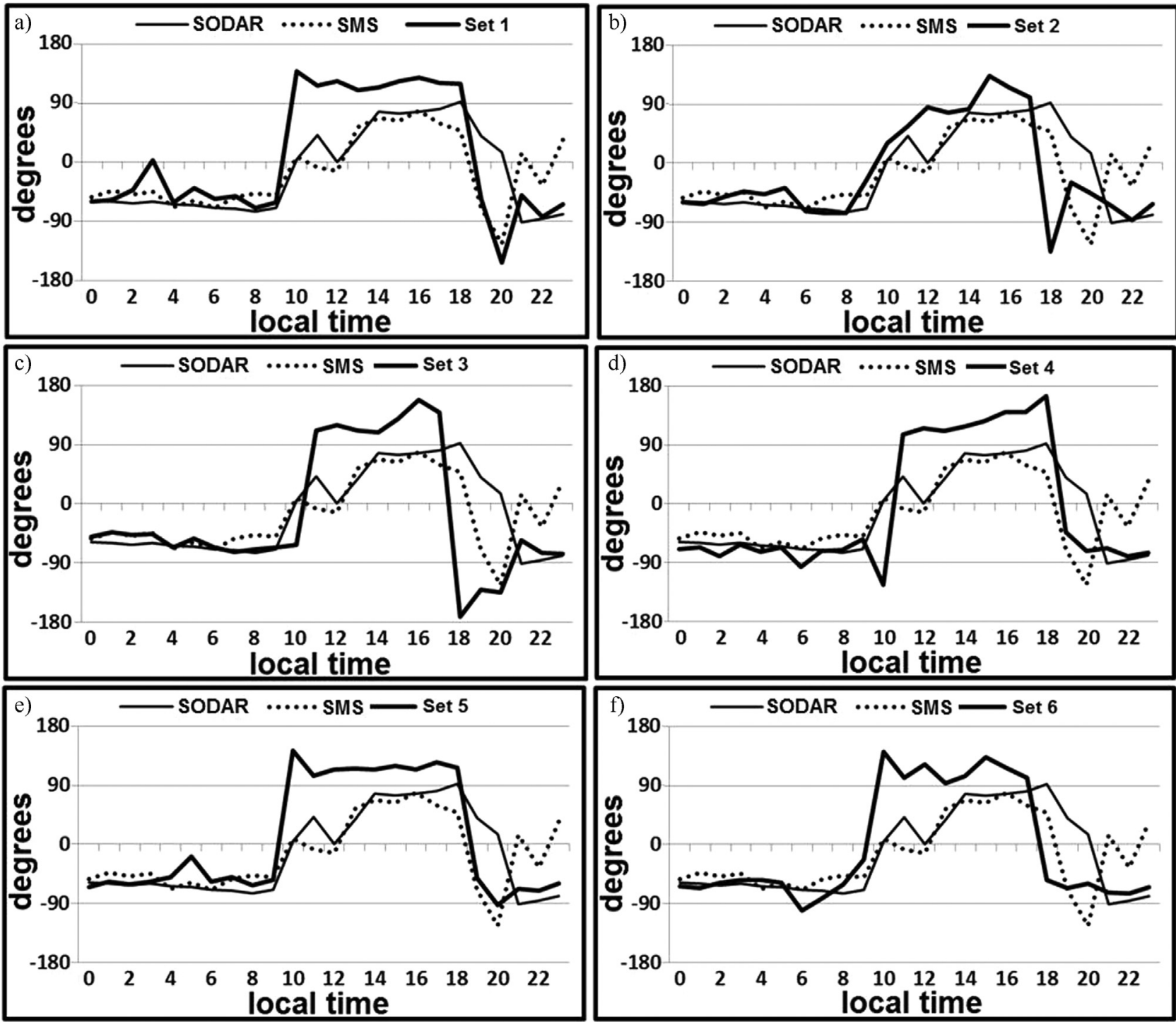

Figure 8 - Wind direction comparison: SODAR (30 m), SMS (10 m) and WRF (10 m)

intense, Sets 1, 2, 5 and 6 also predicted increased vertical speed during the identical period with a temporal distribution that was reasonably similar to that generated by SODAR.

Figure 8 shows a comparison between the wind direction obtained by SODAR at $30 \mathrm{~m}$, those inferred by the WRF model at $10 \mathrm{~m}$, and those measured by SMS at $10 \mathrm{~m}$.

Considering the wind direction changes, all sets of model parameterizations showed that breeze entered between 9:00 and 10:00, when SMS recorded a sharp change in direction from approximately $315 \mathrm{NW}$ to much closer to north. However, the SMS only recorded the effective entry of the sea breeze at approximately 13:00, when it showed an angle of approximately $45 \mathrm{NE}$. Despite an angular error greater than approximately 40 degrees during the period with the sea breeze, Sets 1, 4 and 5, which had approximately equal behaviors, were closest to the values detected by the instruments, inferring breeze entry at the first change of direction captured by SMS and SODAR at 10:00.

The wind speed behavior throughout the day is shown in Fig. 9, where the results of the WRF model at $10 \mathrm{~m}$ are compared with those of SMS at $10 \mathrm{~m}$ and SODAR at the initial height of $30 \mathrm{~m}$.

During the day, all WRF model parameterizations showed reasonable accuracy compared to the values obtained by SMS, but at night, they overestimated the speed values. Although speed was obtained by SODAR at an initial height of $30 \mathrm{~m}$, which resulted in a larger value, SODAR detected smaller values than those measured by SMS. This result was because SODAR detects $u$ and $v$ velocity values in a 60-minute period and records the average resulting velocity vector every $30 \mathrm{~min}$, whereas SMS records the average scalar value of speed every $60 \mathrm{~min}$. 

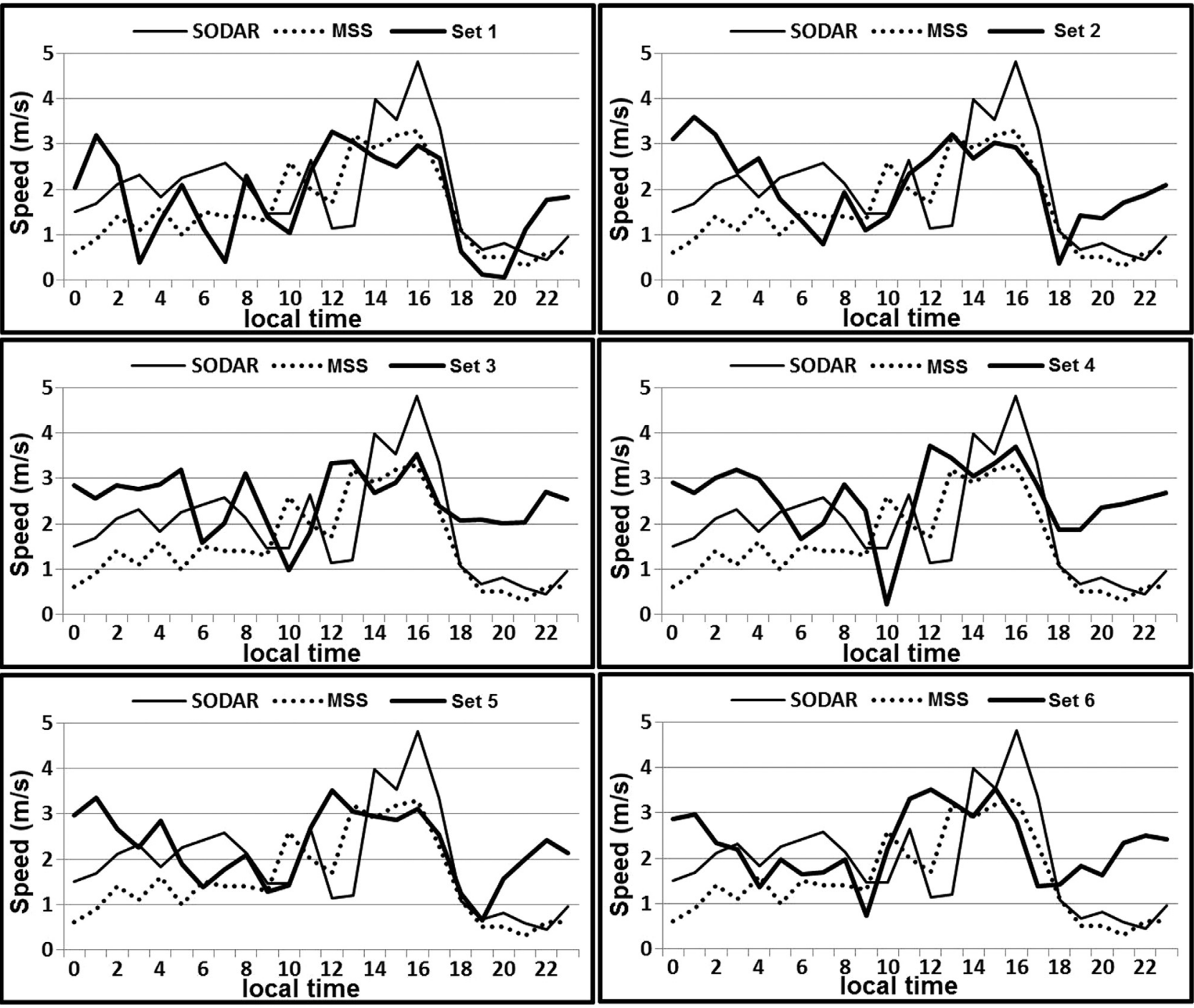

Figure 9 - Wind speed comparison: SODAR (30 m), SMS (10 m) and WRF (10 m).

In Fig. 10, the horizontal wind field predicted by Set 5 of the WRF model is represented at four moments that generally showed more consistent results with the data obtained by the measurement instruments.

The wind fields shown by the vectors characterized three situations: where land breeze could be initially perceived $(0: 00)$, a lower wind speed and tendency to change direction (9:00) and an advancing sea breeze over the study domain between 11:00 and 12:00.

A statistical analysis of the confrontation between the surface station data and WRF at $10 \mathrm{~m}$ (not shown) showed that there was a good correlation coefficient $(\mathrm{R}>90)$ between the sets for speed, direction and temperature. However, the statistical results did not allow us to determine whether a given set of parameterizations showed better accuracy except for wind direction, in which Set 5 obtained slightly better results.
Although local radiosondes were conducted outside of the time period when the sea breeze occurred in the area, as shown in Figs. 11 and 12, the accuracy of the inferences generated by Set 5 of the WRF model was evaluated compared to the data obtained by two radiosondes at 9:00 and 21:00 (local time).

Observing the graphs in Fig. 11, it appears that the prediction generated by Set 5 of the WRF model can reasonably infer the temporal variation for the four variables analyzed (mixing ratio, temperature, wind speed and wind direction) compared to the radiosonde data obtained at 9:00. The sharp decrease in the mixing ratio coincided with the height of the residual layer (approximately 2,000 m) at 9:00, as shown in Fig. 4. In addition, at approximately $400 \mathrm{~m}$, a smooth deviation is noticeable in the curve of the radiosonde data (coincident with LIDAR data detecting the 


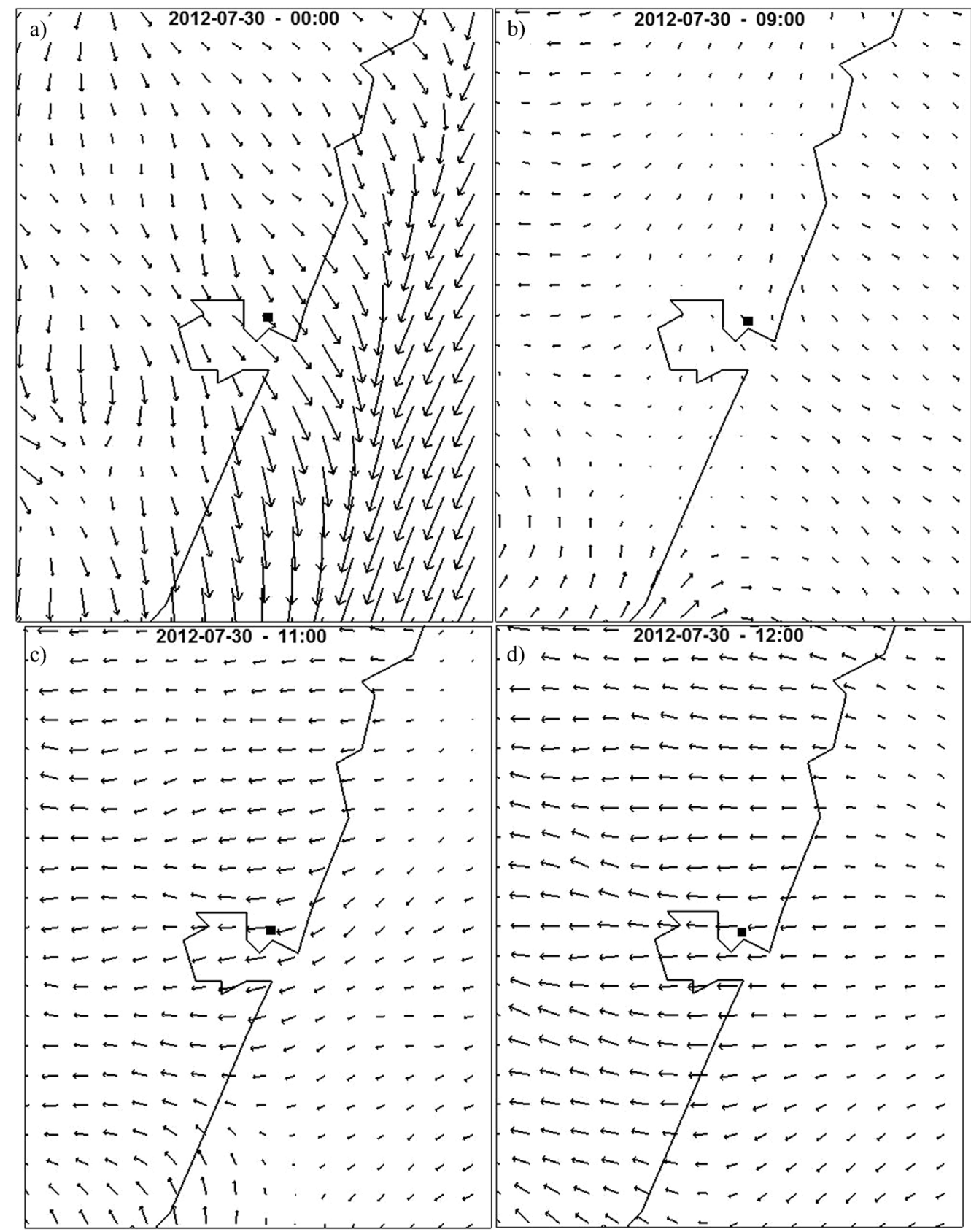

Figure 10 - Wind vectors estimated by Set 5 in the WRF model.

$\mathrm{ABL}$ ), wherein the mixing ratio of the WRF model decays roughly with this deviation.

Compared with the data obtained by the radiosonde at 21:00, the data inferred by Set 5 of the WRF model did not show satisfactory accuracy for wind direction at low altitudes (less than $200 \mathrm{~m}$ ) but showed good accuracy for the other variables above $200 \mathrm{~m}$.

\subsection{A brief discussion of atmospheric boundary layer height}

The formula for diagnosing ABL $(h)$ height is specific for each parameter. YSU and AMC2 determine the top of the ABL, where the bulk Richardson number exceeds a critical value, and the YSU design calculates the bulk Richardson number based on surface soil. Local designs of the $\mathrm{ABL}$, of the MYJ type, define this height as where the turbulent kinetic energy decreases to a prescribed value. According to the results, the YSU design showed a more satisfactory performance in determining ABL height in sea breeze conditions in the GVR for the study day. Furthermore, the results suggest that the Noah parameterization could best capture the energy balance information in the soil. 

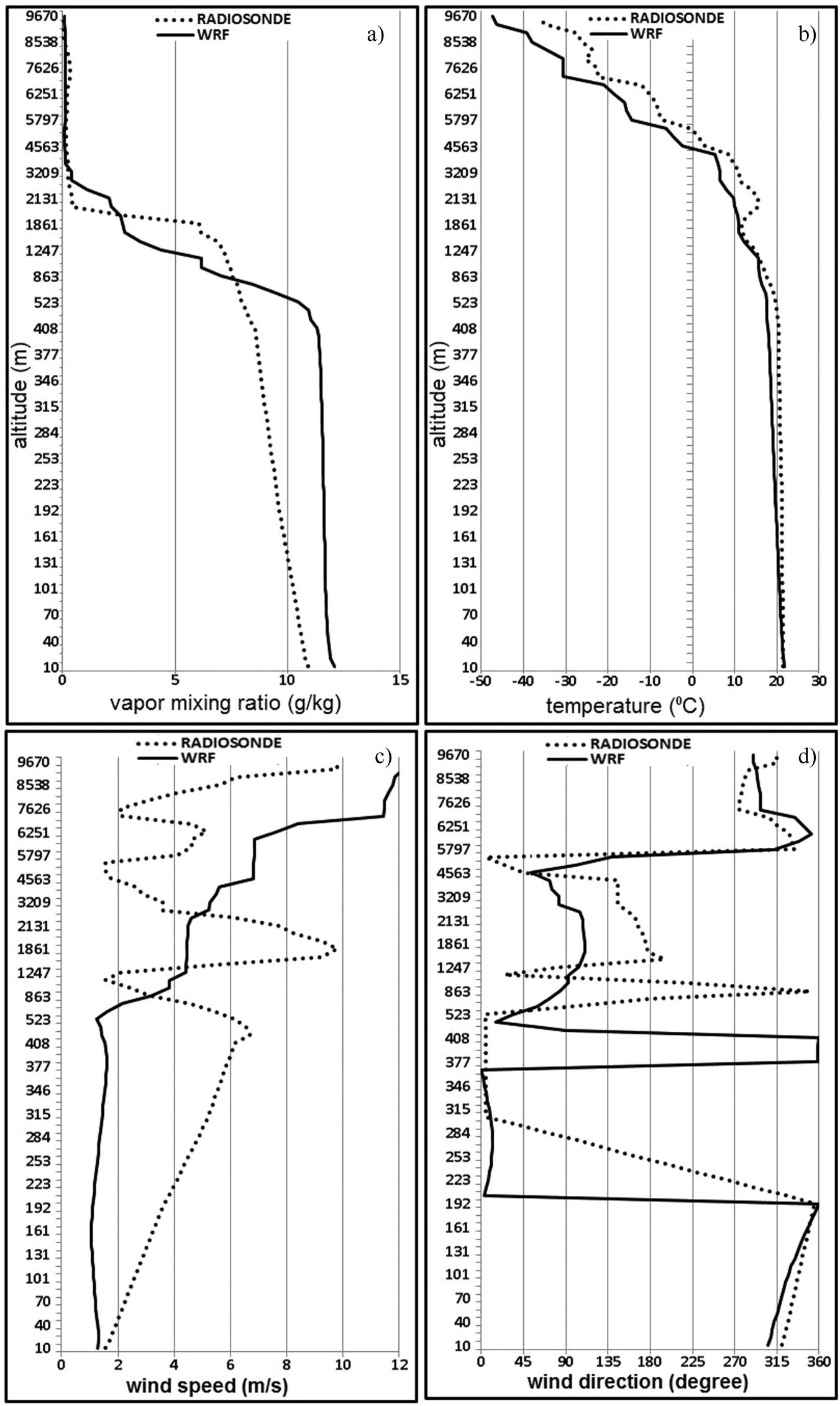

Figure 11 - Comparison WRF / Radiosonde (09:00 - local time). 

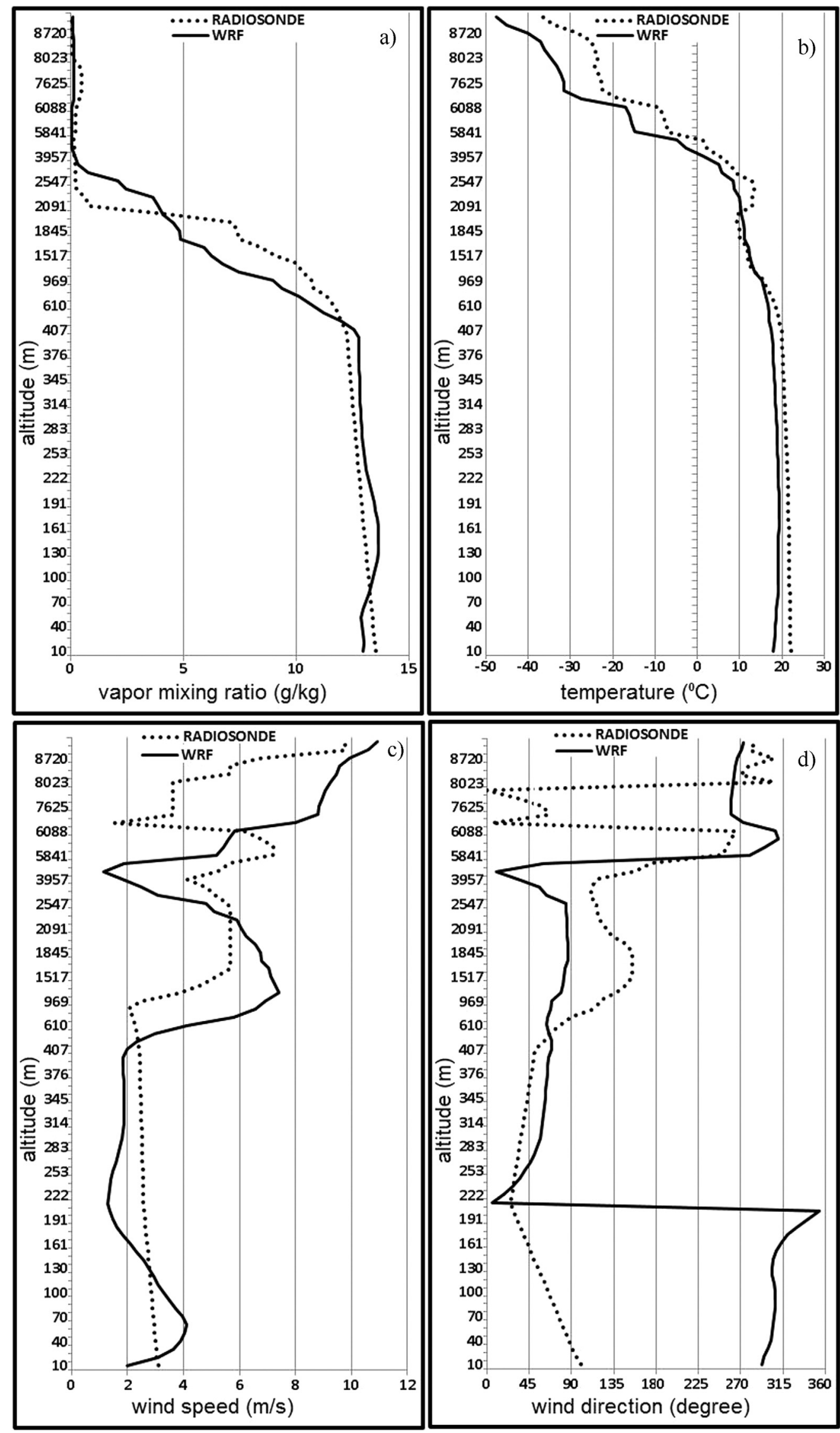

Figure 12 - Comparison WRF / Radiosonde (21:00 - local time). 
Height $h$ is important in atmospheric models because this height is used for other physical parameterizations. Explicitly, the methods for determining the ABL height are not identical to the designs tested. In the YSU design for unstable conditions, the height is determined as the first neutral level by checking the bulk Richardson number between the lowest level (z1) and upper levels (Hong et al., 2006). In the ACM2 design, the method is similar to that of YSU; ABL height is detected as the height of the neutral floatation level where the bulk Richardson number for entrainment exceeds a critical value (Pleim, 2007b). Diffusive profiles are limited to heights below $z=h$ in both designs because of the profiles predicted for the diffusion coefficient $K$. Thus, ABL height and temperature profiles are directly connected to these two designs. However, in the MYJ design, ABL height is detected as the height where the TKE reaches a sufficiently small value. Then, in this design, there was no direct connection between ABL height and temperature profile.

The results suggest that variations among the designs for determining breeze entry are mainly because of differences between the intensities of vertical mixing and the ability of the soil parameterization to account for surface temperature. The surface processes, such as radiation and evapotranspiration exchanges, govern the balance of heat flow radiation, which strongly influences air temperature and humidity at the ground level and the development of the ABL/TIBL. In particular, the prediction of the soil temperature and surface moisture are critical to achieving success in predictions of moisture and heat exchange between the surface and atmosphere. These results show that further verifications of the designs are necessary using additional experimental observations, which are planned for the near future in the GVR, including sampling with more days of breeze for a better characterization of the event. However, it is noteworthy that it is also difficult to determine the entry of a breeze and TIBL height more precisely when obtaining input data in more accurate dispersion models.

\section{Conclusions}

The present study evaluated the ability of some sets of physical parameterizations used in a WRF atmospheric model to describe the $\mathrm{ABL}$ and, in particular, the dynamics of the TIBL created by the sea breeze in a coastal region with complex topography. The results showed that although inferences have been generated for a single point of the domain and for only one day, the data inferred by the WRF model reasonably represented the structure of the atmosphere in the study region. Although all six sets of parameterizations detected the occurrence of a sea breeze in the region, the set that used the YSU parameterization with Noah (Set 5) presented a more satisfactory result for both the behavior of surface wind direction and for the time frame of the occurrence and height of the TIBL created by the sea breeze. In practice, this result suggests that if the data resulting from this set of parameterizations (Set 5) are used as input data in a model of air pollutant dispersion, more reliable results can be obtained.

In the WRF model simulations, input data provided by the archive generated by the USGS were used that describe the type of soil and its occupation and geographical singularities with a horizontal grid of approximately $1 \mathrm{~km}$. These data are obtained by surveys, along with other methods, conducted using responses to radar and LIDAR signals attached to airplanes and satellites that, in principle, suggest they are not faithfully translating all spatial variations that occur in use and occupation. Future studies may lead to improvements in simulations with more detailed and updated information on soil in the GVR, including higher spatial resolution in the model.

\section{References}

BELL, M.L.; DAVIS, D.L.; GOUVEIA, N.; BORJA-ARBURTO, V.H.; CIFUENTES, L.A. The avoidable health effects of air pollution in three Latin American cities: Santiago, São Paulo and Mexico City. Environment Research, v. 100, n. 3, p. 431-440, 2006.

BORREGO, C.; MONTEIRO, A.; FERREIRA, J.; MORAES, M.R.; CARVALHO, A.; RIBEIRO, I.; MIRANDA, A.I.; MOREIRA, D.M. Modelling the photochemical pollution over the metropolitan area of Porto Alegre, Brazil. Atmospheric Environment, v. 44, n. 20, p. 370-380, 2010.

HERNANDÉZ-CEBALLOS, M.A.; ADAME, J.A.; BOLIVAR, J.P.; DE LA MORENA, B.A. A mesoscale simulation of coastal circulation in the Guadalquivir valley (southwestern Iberian Peninsula) using the WRF-ARW model, Atmospheric Research, v. 124, n. 1, p. 1-20, 2013.

CHALLA, V.S.; INDRACANTI, J.; RABARISON, M.K.; PATRICK, C.; BAHAM, J.M.; YOUNG, J.; HUGHES, R.; HARDY, M.G.; SWANIER, S.J.; YERRAMILLI, A. A simulation study of mesoscale coastal circulations in Mississippi Gulf coast. Atmospheric Research, v. 91, n. 1, p. 9-25, 2009.

CHEMEL, C.; SOKHI, R.S. Response of London's urban heat island to a marine air intrusion in an easterly wind regime. Boundary-Layer Meteorology, v. 144, n. 2, p. 65-81, 2012.

CHEN, F.; DUDHIA, J. Coupling an advanced land surfacehydrology model with the Penn State-NCAR MM5 Modeling System. Part I: Model Implementation and Sensitivity. Monthly Weather Review, v. 129, n. 9, p. 569-585, 2001.

CHENG, F.Y.; CHIN, S.C.; LIU, T.H. The role of boundary layer shemes in meteorological and air quality simulations of the Taiwan area. Atmospheric Environment, v. 54, n. 1, p. 714-727, 2012.

CHIBA, O. Variability of the sea-breeze front from sodar measurements. Boundary-Layer Meteorology, v. 82, n. 1, p. 165-174, 1997.

CLAPP, R.B.; HORNBERGER, G.M. Empirical equations for some soil hydraulic properties. Water Resources Research, v. 14, n. 5, p. 601-604, 1978.

DANDOU, A.; TOMBROU, M.; SOULAKELLIS, N. The influence of the City of Athens on the evolution of the sea-breeze 
front. Boundary-Layer Meteorology, v. 131, n.1, p. 35-51, 2009.

DE LEÓN, S.P.; ORFILA, A. Numerical study of the marine breeze around Mallorca Island. Applied Ocean Research, v. 40, n. 1, 26-34, 2013.

DELBARRE, H., AUGUSTIN, P., SAID, F., CAMPISTRON, B., BÉNECH, B., LOHOU, F., PUYGRENIER, V., MOPPERT, C., COUSIN, F., FRÉVILLE, P.; FRÉJAFON, E. Ground-based remote sensing observation of the complex behavior of the Marseille boundary layer during ESCOMPTE. Atmospheric Research, v. 74, n. 3, p. 403-433, 2005.

DE TOMASI, F.; MIGLIETTA, M.; PERRONE, R. The growth of the Planetary Boundary Layer at a coastal site: a case study. Boundary-Layer Meteorology, v. 39, n. 5, p. 521541, 2011.

ESTOQUE, M.A. The Sea Breeze as a Function of the Prevailing Synoptic Situation. Journal of the Atmospheric Sciences, v. 19, n 1, p. 244-250, 1962.

FISHER, E.L. A theoretical study of the sea breeze. Journal of Meteorology, v 18, n. 2, p. 216-233, 1961

GILLIAM, R.C.; RAMAN, S.; NIYOGI, D.S. Observational and numerical study on the influence of large-scale flow direction and coastline shape on sea-breeze evolution. Boundary-Layer Meteorology, v. 111, p. 275-300, 2004.

HAURWITZ, B. Comments on the Sea-Breeze Circulation. Journal of Meteorology, v. 4, p. 1-8, 1947.

HONG, S.Y.; NOH, Y.; DUDHIA, J. A new vertical diffusion package with explicit treatment of entrainment processes. Monthly Weather Review, v. 134, n. 9, p. 2318-2341, 2006.

JANJIC, Z.I. The step-mountain eta coordinate model: further developments of the convection, viscous layer and turbulence closure schemes. Monthly Weather Review, v. 122, p. 927-945, 1994.

KALA, J.; LYONS, T.J.; ABBS, D.J.; NAIR, U.S. Numerical simulations of the impacts of land-cover change on a southern sea breeze in south-west western Australia. Boundary-Layer Meteorology, v. 135, n.3, p. 485-503, 2010.

LANDULFO, E.; FREITAS, S.R.; LONGO, K.M.; UEHARA, S.T.; SAWAMURA, P. A comparison study of regional atmospheric simulations with an elastic backscattering Lidar and sun photometry in an urban area. Atmospheric Chemistry and Physics, v. 9, n. 14, p. 6767-6774, 2009.

LANDULFO, E.; MATOS, C.A.; TORRES, A.S.; SAWAMURA, P.; UEHARA, S.T. Air quality assessment using a multi-instrument approach and air quality indexing in an urban area. Atmospheric Research, v. 85, n. 1, p. 98-111, 2007.

LEVY, I.; MAHRER, Y.; DAYAN, U. Coastal and synoptic recirculation affecting air pollutants dispersion: a numerical study. Atmospheric Environment, v. 43, n. 12, p. 19911999, 2009.

MELLOR, G.L.; YAMADA, T. Development of a turbulence closure model for geophysical fluid problems. Reviews of Geophysics and Space Physics, v. 20, n. 4, p. 851-875, 1982.

MENDONÇA, R.W.B.; BONATTI, J.P. Estudo da Energética Modal para Episódios de ZCAS. Parte II: Impacto da Resolução do Modelo e da Parametrização de Convecção [Study of the Modal Energetics for SACZ Episodes. Part II: Impact of the Model Resolution and the Convection
Parameterization]. Revista Brasileira de Meteorologia, v. 23 , n. 4, p. 381-403, 2008

MILLER, S.T.K.; KEIM, B.D.; TALBOT, R.W.; MAO, H. Sea breeze: structure, forecasting and impacts. Reviews of Geophysics, v. 41, n. 1, p. 1-31, 2003.

MOLINA, C.; TIJM, S.; EBERT, E.E.; SERRANO, S.; ESTRELA, M.J. High resolution HIRLAM simulations of the role of low-level sea-breeze convergence in initiating deep moist convection in the eastern Iberian Peninsula. Boundary-Layer Meteorology, v. 154, n. 1, p. 81-100, 2014.

MUPPA, S.K.; ANANDAN, V.K.; KESARKAR, K.A.; RAO, S.V.V.; REDDY, P.N. Study on deep inland penetration of sea breeze over complex terrain in the tropics. Atmospheric Research, v. 104, n. 1, p. 209-216, 2012.

PAPANASTASIOU, D.K.; MELAS, D.; LISSARIDS, I. Study of wind field under sea breeze conditions; an application of WRF model. Atmospheric Research, v. 98, n. 1, p. 102117,2010

PLEIM, J.E.; CHANG, J.S. A non-local closure model for vertical mixing in the convective boundary layer. Atmospheric Environment, v. 26-A, n. 18, p. 965-968, 1992.

PLEIM, J.E. A combined local and nonlocal closure model for the atmospheric boundary layer. Part I: Model description and testing. Journal of Applied Meteorology and Climatology, p. 46, n. 9, p. 1383-1395, 2007a.

PLEIM, J.E. A combined local and nonlocal closure model for the atmospheric boundary layer. Part II: Model description and testing. Journal of Applied Meteorology and Climatology, p. 46, n. 9, p. 1396-1409, 2007b.

PUYGRENIER, V.; LOHOU, F.; CAMPISTRON, B.; SAID, F.; PI GEON, G.; BENECH, B.; SERCA, D. Investigation on the fine structure of sea-breeze during ESCOMPTE experiment. Atmospheric Research, v. 74, n. 1, p. 329-353, 2005.

RYU, Y.; BAIK, J.; HAN, J. Daytime urban breeze circulation and its interaction with convective cells. Quarterly Journal of the Royal Meteorological Society, v. 139, n. 673, p. 401-413, 2012.

SALDIVA, P.H.; POPE, C.A.; SCHWARTZ, J.; DOCKERY, D.W.; LICHTENFELS, A. J.; SALGE, J. M.; BARONE, I.; BOHM, G.M. Air pollution and mortality in elderly people: a time-series study in São Paulo, Brazil. Arch Environ Health, v. 50, n. 4, p. 159-63, 1995.

SIMPSON, J.E. Sea breeze and local winds. Cambridge University Press, 234 pp, 1994.

SIMPSON, J.E. Diurnal changes in sea-breeze direction. Journal of Applied Meteorology, v. 35, n. 7, p. 1166-1169, 1996.

SKAMAROCK, W.C.; KLEMP, J.B.; DUDHIA, J.; GILL, D.O.; BARKER, D.M.; DUDA, M.G.; HUANG, X.Y.; WANG, W.; POWERS, J.G. A description of the advanced research WRF Version 3. NCAR Technical Note. NCAR/TN-468 STR, 88 pp, 2008.

SMIRNOVA, T.G.; BROWN, J.M.; BENJAMIN, S.G.; KIM, D. Parameterization of cold-season processes in the MAPS land-surface scheme. Journal of Geophysical Research, v. 105, n. D3, p. 4077-4086, 2000.

SOLER, M.R.; ARASA, R.; MERINO, M.; OLID, M. Modelling local sea-breeze flow and associated dispersion patterns over a coastal area in north-east Spain: a case study. Boundary-Layer Meteorology, v. 140, n. 1, p. 37-56, 2011.

STULL, R.B. An introduction to boundary layer meteorology. Springer Publishing, New York, 670 pp, 1988. 
TALBOT, C.; AUGUSTIN, P.; LEROY, C.; WILlART, V.; DELBARRE, H.; KHOMENKO, G. Impact of a sea-breeze on the boundary-layer dynamics and the atmospheric stratification in a coastal area of the North Sea. Boundary-Layer Meteorology, v. 125, n. 1, p. 133-154, 2007.

VARQUEZ, A.C.; NAKAYOSHI, M.; KANDA, M. The effects of highly detailed urban roughness parameterrs on a sea- breeze numerical simulation. Boundary-Layer Meteorology, v. 154, n. 3, p. 449-469, 2015.

WANG, W.; SEAMAN, N.L. A comparison study of convective parameterization schemes in a mesoscale model. Monthly Weather Review, v. 125, n. 2, p. 252-278, 2007.

This is an Open Access article distributed under the terms of the Creative Commons Attribution Non-Commercial License which permits unrestricted non-commercial use, distribution, and reproduction in any medium provided the original work is properly cited. 